\title{
NOTE ON A LI-STEVIĆ INTEGRAL-TYPE OPERATOR FROM MIXED-NORM SPACES TO $n$ TH WEIGHTED SPACES
}

\author{
HAIYING Li AND ZHITAO GUO
}

Abstract. The boundedness and compactness of a Li-Stević integral-type operator from mixednorm spaces to $n$th weighted spaces are characterized in this paper.

Mathematics subject classification (2010): Primary 47B38; 30H05.

Keywords and phrases: Boundedness, compactness, mixed-norm spaces, $n$th weighted spaces.

\section{REFERENCES}

[1] K. Esmaeili, M. Lindström, Weighted composition operators between Zygmund type spaces and their essential norms, Integr. Equ. Oper. Theory, 75 (2013), 473-490.

[2] Z. J. Hu, Extended Cesáro operators on mixed norm spaces, Proc. Amer. Math. Soc. 131 (7) (2003), 2171-2179.

[3] H. LI, T. MA, Z. GUo, Generalized composition operators from Zygmund type spaces to $Q_{K}$ spaces, J. Math. Inequal. 9 (2) (2015), 425-435.

[4] S. Li, S. STEvić, Composition followed by differentiation from mixed-norm spaces to $\alpha$-Bloch spaces, Sb. Math. 199 (12) (2008), 1847-1857.

[5] S. Li, S. STEVIĆ, Generalized composition operators on Zygmund spaces and Bloch type spaces, J. Math. Anal. Appl. 338 (2) (2008), 1282-1295.

[6] S. Li, S. STEVIĆ, Generalized weighted composition operators from $\alpha$-Bloch spaces into weightedtype spaces, J. Inequal. Appl. Vol. 2015, Article no. 265, (2015), 12 pages.

[7] Y. LIU, Y. YU, The multiplication operator from mixed-norm spaces to $n$-th weighted-type spaces on the unit disk, Math. Inequal. Appl. 15 (2) (2012), 437-448.

[8] H. J. Schwartz, Composition operators on $H^{p}$, Thesis, University of Toledo, 1969.

[9] A. ShieldS, D. Williams, Bounded projections, duality, and multipliers in spaces of analytic functions, Trans. Amer. Math. Soc., 162 (1971), 287-302.

[10] S. STEVIĆ, Generalized composition operators from logarithmic Bloch spaces to mixed-norm spaces, Util. Math. 77 (2008), 167-172.

[11] S. STEvić, On a new operator from $H^{\infty}$ to the Bloch-type space on the unit ball, Util. Math. 77 (2008), 257-263.

[12] S. STEVIĆ, Products of integral-type operators and composition operators from the mixed norm space to Bloch-type spaces, Siberian Math. J. 50 (4) (2009), 726-736.

[13] S. STEviĆ, On an integral-type operator from logarithmic Bloch-type and mixed-norm spaces to Bloch-type spaces, Nonlinear Anal. TMA 71 (2009), 6323-6342.

[14] S. STEVIĆ, Integral-type operators from a mixed norm space to a Bloch-type space on the unit ball, Siberian Math. J. 50 (6) (2009), 1098-1105.

[15] S. STEVIĆ, On an integral operator from the Zygmund space to the Bloch-type space on the unit ball, Glasg. J. Math. 51 (2009), 275-287.

[16] S. STEvić, Composition operators from the weighted Bergman space to the $n$th weighted spaces on the unit disc, Discrete Dyn. Nat. Soc. vol. 2009, Article ID 742019, 11 pages, 2009.

[17] S. STEVIĆ, Weighted differentiation composition operators from the mixed-norm space to the nth weigthed-type space on the unit disk, Abstr. Appl. Anal. 2010 (2010), Article ID 246287, 15 pages.

[18] S. STEVIĆ, On an integral-type operator from logarithmic Bloch-type spaces to mixed-norm spaces on the unit ball, Appl. Math. Comput. 215 (11) (2010), 3817-3823. 
[19] S. STEvić, Weighted differentiation composition operators from $H^{\infty}$ and Bloch spaces to $n$th weighted-type spaces on the unit disk, Appl. Math. Comput. 216 (12) (2010), 3634-3641.

[20] S. STEVIĆ, On operator $P_{\varphi}^{g}$ from the logarithmic Bloch-type space to the mixed-norm space on unit ball, Appl. Math. Comput. 215 (2010), 4248-4255.

[21] S. STEVIĆ, Weighted radial operator from the mixed-norm space to the nth weighted-type space on the unit ball, Appl. Math. Comput. 218 (2012), 9241-9247.

[22] S. STEVIĆ, S. I. UeKI, On an integral-type operator between weighted-type spaces and Bloch-type spaces on the unit ball, Appl. Math. Comput. 217 (2010), 3127-3136. 